Article

\title{
Formation and Continuation of Thermal Energy Community Systems: An Explorative Agent-Based Model for the Netherlands
}

\author{
Javanshir Fouladvand ${ }^{1, *}$, Niek Mouter ${ }^{2}$, Amineh Ghorbani ${ }^{1}$ and Paulien Herder ${ }^{3}($ ) \\ 1 Energy and Industry Section, Engineering Systems and Services Department, Technology, \\ Policy and Management Faculty, Delft University of Technology (TU Delft), 2628 BX Delft, The Netherlands; \\ A.Ghorbani@tudelft.nl \\ 2 Transports and Logistics, Engineering Systems and Services Department, Technology, \\ Policy and Management Faculty, Delft University of Technology (TU Delft), 2628 BX Delft, The Netherlands; \\ N.Mouter@tudelft.nl \\ 3 Process and Energy Department, Mechanical, Maritime and Materials Engineering Faculty, \\ Delft University of Technology (TU Delft), 2628 CB Delft, The Netherlands; P.M.Herder@tudelft.nl \\ * Correspondence: j.fouladvand@tudelft.nl; Tel.: +31-(0)6-84-08-52-68
}

Received: 17 March 2020; Accepted: 26 May 2020; Published: 2 June 2020

\begin{abstract}
Energy communities are key elements in the energy transition at the local level as they aim to generate and distribute energy based on renewable energy technologies locally. The literature on community energy systems is dominated by the study of electricity systems. Yet, thermal energy applications cover $75 \%$ of the total energy consumption in households and small businesses. Community-driven initiatives for local generation and distribution of thermal energy, however, remain largely unaddressed in the literature. Since thermal energy communities are relatively new in the energy transition discussions, it is important to have a better understanding of thermal energy community systems and how these systems function. The starting point of this understanding is to study factors that influence the formation and continuation of thermal energy communities. To work towards this aim, an abstract agent-based model has been developed that explores four seemingly trivial factors, namely: neighborhood size, minimum member requirement, satisfaction factor and drop-out factor. Our preliminary modelling results indicate correlations between thermal community formation and the 'formation capability' (the percentage of households that joined) and with the satisfaction of households. No relation was found with the size of the community (in terms of number of households) or with the 'drop-out factor' (individual households that quit after the contract time).
\end{abstract}

Keywords: energy community; thermal energy systems; agent-based modelling and simulation; formation and continuation; critical factors

\section{Introduction}

All around the world, energy systems are going through a transition [1-3]. The energy transition, mainly fuelled by climate change, requires a concerted change in technological developments and institutional settings, while not hampering economic growth. This transition is being discussed and executed at different scales: international, national, regional and local [4,5]. Energy communities are considered key by many scholars and politicians for realizing the energy transition at the local level as they allow the generation and distribution of renewable energy at the local level [6,7].

There are different definitions of energy communities. Energy cooperatives, as more formal energy communities, enable citizens who participate to collectively own and manage renewable energy projects at the local level [8]. Based on this organizational model, participants generate, and in some 
cases, consume renewable energies. One of the most important aspects of energy cooperatives is that they are commercial organizations that operate in a market [8,9]. Energy communities, however, are projects/organizations that, in addition to financial benefits, also consider other aspects, such as environmental concerns [10]. In other words, apart from possible financial benefits, environmental concerns, norms and values also play important roles in energy communities [11,12]. While an energy cooperative's goal is mainly to generate financial benefits (by generating, participating in the market and consuming in some cases), in energy communities, generation and distribution of renewable energy are for the participants' consumption to address goals, including environmental concerns and financial benefits. Therefore, leadership, membership and interactions between the energy community participants are important [13].

In a broad sense, [14] defined an energy community as "a group of consumers and/or prosumers, that together share energy generation units and electricity storage". Energy communities are also presented as initiatives that focus on renewable energy generation, distribution and consumption (including considering energy-saving measures) for all involved stakeholders $[15,16]$. In this study as [7] defines, we consider an energy community as the combination of a technical energy system (mainly renewable energy technology) on the local level (e.g., an urban neighbourhood), its associated group of stakeholders that share common interest(s) and problem(s), and institutions (formal and informal rules) that govern these systems. Participants and stakeholders of an energy community share resources and collaborate on energy generation, distribution and conservation processes $[9,12]$. Typical energy community characteristics are: operation at the local scale, community engagement, participatory decision-making, involvement of local actors and distribution of financial resources [17]. Different stakeholders (including households) who decide to participate in an energy community, would have different roles, such as leader [13] or investor/shareholder [18].

Recent literature on the establishment and management of community energy systems predominantly focuses on electricity systems (e.g., $[4,7,19,20])$. However, thermal energy plays an important role in the urban context, as it is used for the purposes of heating, cooling, bathing, showering and cooking, covering approximately $75 \%$ of the non-transport related energy consumption among households $[19,21,22]$. Although heating energy cooperatives (such as district heating cooperatives) are discussed in the literature (e.g., [23-25]), thermal energy communities are relatively understudied. It is meaningful to study whether thermal energy communities are sustained over time and, if so, which factors influence their formation and continuity or decline. Such study will increase our understanding of thermal energy community (TEC) initiatives, how TECs would function and what factors are more important to consider to facilitate their formation and continuity. In this paper, we present the basis of an agent-based simulation model that provides insights into factors influencing the formation and continuation of TEC initiatives.

The structure of the paper is as follows: The next section presents the methods that were used in this research. Section 3 presents the data collection procedure. The structure of the abstract model is presented in Section 4. Section 5 discusses the model results. The model's limitations are presented in Section 6. Finally, Section 7 provides a discussion and conclusions.

\section{Research Methods}

A literature review and several interviews were conducted to first deepen our understanding of factors that influence the formation and continuation of thermal energy communities (TECs). The literature review was based on peer-reviewed material collected from scholarly databases, www.scopus.com and www.sciencedirect.com, using keywords including: "energy community/ies", "thermal energy community/ies", "heat energy community/ies", "thermal community energy systems", "factors of thermal energy community/ies", "formation of thermal energy community/ies" and "agent-based modelling AND thermal energy community". As the existing literature on TEC (including both thermal/heat energy systems and community energy systems) was relatively small, articles that focus on community energy systems, in general, were also included. The focus of this literature 
review was to provide an understanding of TECs and the factors which influence their formation and continuation. Therefore, in this step, a snowballing method was used, focusing on the most cited articles. In the next round, backward snowballing was applied, reviewing the articles that were cited in the articles found in the first round of snowballing. Furthermore, since the peer-reviewed literature related to TECs is relatively small, non-peer-reviewed documents cited in the reviewed articles were also considered, which led to a better understanding of the factors that have influence on the formation and continuation of TECs.

To delineate and focus on the important and unexplored factors, nine semi-structured interviews with main stakeholders in the Netherlands (policy makers, municipalities, community's presenters, energy companies and researchers) were conducted. These stakeholders were closely involved in projects related to local thermal energy transition in the Netherlands and were already working on TECs projects. The focus of the interviews was on TECs and on discovering the main factors and narrowing them down to a selected number of factors that influence their formation and continuation. Interviewees were explicitly asked to discuss the main factors which influence the formation and continuation of TECs. The interviews were transcribed, and the mentioned factors were extracted.

To deepen the understanding of the influence of these factors on the formation and continuation of TECs, there is a need for a set of experiments. In such experiments, measures related to the formation and continuation of TECs can be studied. However, performing these experiments in the real world would be time-consuming and costly and would have an actual, not necessarily beneficial, impact on individuals' lives [26,27]. Therefore, given the complexity of TECs and lack of possibility to perform a wide and varied set of experiments in the real world, a simulation model can provide benefits of experiments more quickly and less costly in a virtual setting. Simulation models that present a simpler version of the real world would help to demarcate certain design options or variables. [28,29].

In our research, we used agent-based modelling and simulation (ABMS) to study TEC initiatives. ABMS is an approach where a system is modelled as a collection of autonomous decision-making entities called agents who interact with each other and the environment [30-32]. In ABMS, Agent-based models consist of a collection of agents and their states, the rules governing the interactions of the agents and the environment within which they live [33,34]. ABMS was selected for our research due to the importance of actors, their decision-making process and interactions within thermal energy community systems, which aligns with the specific strengths of agent-based modelling $[35,36]$. Due to the complexity of the real world, an agent-based model cannot represent all of the details of a real-world decision-making process. However, ABMS could facilitate decision-makers by equipping them with insights about crucial variables affecting the decision-making process, thereby allowing decision-making in a less time-consuming and costly way. A sensitivity analysis [37] was conducted for various model parameters to explore various experimental configurations. The results of the model were evaluated through expert interviews.

\section{Data Gathering}

\subsection{Literature Review}

The literature on energy communities is mainly dominated by electricity systems (e.g., $[4,19,20])$. However, since thermal energy applications, such as heating, cooling, bathing, showering and cooking, cover $75 \%$ of energy consumption among the households, it is vital also to discuss thermal energy systems and communities (TECs) and their related challenges.

Based on the literature and studies, such as [13-16], we defined TECs based on three main components: a renewable energy technology (for thermal applications), involved stakeholders and related institutions. The technology component includes generation, distribution and consumption of thermal energy $[38,39]$. Involved actors and their roles $[13,40]$ are related to stakeholders component. Finally, the institutional component covers both formal and informal institutions that govern an energy community $[6,12,41]$. 
TECs have technical, social and governance challenges. These challenges can be translated into factors that influence the formation and continuation of TEC initiatives. System challenges, such as system design, system efficiency and intermittency in generation and use, have been discussed in the literature (e.g., [42-44]).

Technical challenges and factors related to infrastructure and thermal technologies are discussed extensively in studies in which authors explore various technologies and integration and deployment of infrastructure in local energy systems (e.g., [20,38,45-47]). Furthermore, there are different studies related to demand-side management and its application for energy communities (e.g., [48-52]). In relation to these technical challenges, reported factors that influence the formation and continuation of (thermal) energy communities are (i) the availability of technology, such as solar thermal technology, geothermal wells or heat pumps (e.g., [53-55]), (ii) available resources for energy generation (e.g., $[9,56]$ ) and (iii) the number of households (e.g., $[57,58])$. Finally, (iv) the influence of the initial community size is also discussed in $[57,59]$.

TEC initiatives also have challenges related to social, governance and economic arrangements. For instance, the involvement and analysis of stakeholders in energy communities is the focus of studies such as $[5,60,61]$. These studies focus on the important role of municipalities and households in energy communities. In this group, important factors for the formation and continuation of (thermal) energy communities that are discussed include trust $[59,62]$ characteristics of participants, such as willingness to participate $[63,64]$ or satisfaction $[56,63-68]$.

Studies such as $[5,45-47,57,67,68]$ are focused on the challenges and factors related to regulation and governance in energy communities. Financial aspects, such as investment, payback time and subsidies, are the focus of $[17,31,56,57,63,69,70]$. The size of the community and investment (e.g., $[4,6,56,71])$ are examples of factors in this group that influences the formation and continuation of (thermal) energy communities. Furthermore, other important factors related to interactions within the community, such as satisfaction and quitting the community (drop-out rates), are also discussed [7,17,31,71-73]. Table 1 presents the most cited studies in recent years, which explicitly focus on different factors and challenges related to energy communities.

Table 1. Studies with a focus on factors and challenges related to energy communities.

\begin{tabular}{|c|c|c|c|c|}
\hline Study & $\begin{array}{c}\text { Year of } \\
\text { Publication }\end{array}$ & Focus of Study ${ }^{1}$ & Domain of Study & $\begin{array}{l}\text { Main Focused } \\
\text { Factor }\end{array}$ \\
\hline [57] & 2007 & $\begin{array}{l}\text { Heat/ thermal energy } \\
\text { communities }\end{array}$ & $\begin{array}{l}\text { Economic, } \\
\text { technological }\end{array}$ & $\begin{array}{l}\text { Available } \\
\text { technologies }\end{array}$ \\
\hline$[64]$ & 2008 & Energy communities & Social & Acceptance \\
\hline [72] & 2008 & Energy communities & Social, institutional & Ownership \\
\hline [12] & 2010 & Energy communities & Social & Trust \\
\hline [47] & 2011 & Energy communities & Technological & $\begin{array}{l}\text { Integration of } \\
\text { infrastructure }\end{array}$ \\
\hline [74] & 2013 & Energy communities & $\begin{array}{l}\text { Technological, } \\
\text { social, economic }\end{array}$ & Reliable \\
\hline [22] & 2013 & $\begin{array}{l}\text { Heat/thermal energy } \\
\text { communities }\end{array}$ & Technological & Emission \\
\hline [42] & 2014 & $\begin{array}{l}\text { Heat/thermal energy } \\
\text { communities }\end{array}$ & Technological & Integration of RETs \\
\hline [6] & 2014 & Energy communities & Institutional & $\begin{array}{l}\text { Incentivizing } \\
\text { policies }\end{array}$ \\
\hline [66] & 2016 & Energy communities & Social & $\begin{array}{l}\text { Willingness to } \\
\text { participate }\end{array}$ \\
\hline
\end{tabular}


Table 1. Cont

\begin{tabular}{|c|c|c|c|c|}
\hline Study & $\begin{array}{c}\text { Year of } \\
\text { Publication }\end{array}$ & Focus of Study ${ }^{1}$ & Domain of Study & $\begin{array}{c}\text { Main Focused } \\
\text { Factor }\end{array}$ \\
\hline [4] & 2016 & Energy communities & $\begin{array}{l}\text { Technological, } \\
\text { socio-economic, } \\
\text { environmental, } \\
\text { institutional }\end{array}$ & $\begin{array}{l}\text { Intermittency in } \\
\text { generation and } \\
\text { demand }\end{array}$ \\
\hline [9] & 2016 & Energy communities & Social, institutional & $\begin{array}{l}\text { Incentivizing } \\
\text { policies }\end{array}$ \\
\hline [62] & 2016 & Energy communities & Social, institutional & Trust and justice \\
\hline [53] & 2017 & Energy communities & Technological & $\begin{array}{l}\text { Available } \\
\text { technologies }\end{array}$ \\
\hline [75] & 2017 & Energy communities & Social & Acceptance \\
\hline [76] & 2017 & Energy communities & Social, institutional & Governance \\
\hline [59] & 2018 & $\begin{array}{c}\text { Heat/thermal energy } \\
\text { communities }\end{array}$ & $\begin{array}{c}\text { Economic, } \\
\text { technological }\end{array}$ & $\begin{array}{c}\text { Available } \\
\text { technologies }\end{array}$ \\
\hline$[11]$ & 2018 & Energy communities & Social & Trust \\
\hline [63] & 2019 & Energy communities & Social & $\begin{array}{l}\text { Willingness to } \\
\text { participate }\end{array}$ \\
\hline [17] & 2019 & Energy communities & Socio-economic & Size of investments \\
\hline [70] & 2019 & Energy communities & Social, economic & Acceptance \\
\hline
\end{tabular}

${ }^{1}$ : In the current literature, studies usually discuss energy communities as a general term for both electricity and heating systems. But the studies which are mentioned as heat/thermal energy communities, specifically focus on heating systems.

As Table 1 shows, a limited number of studies [22,42,57,59] (gray rows in the table) specifically discuss the challenges and factors of TEC initiatives in depth. The available studies mainly focus on technical challenges. In the scarce literature on influencing factors related to energy communities, factors such as the size of the community, financial aspects (e.g., cost and investment) or satisfaction of participants (with relation to financial and social aspects) are studied through empirical studies, such as $[17,62,72]$. However, the computer modelling of these factors is rarely explored. According to the literature, besides technical challenges, trust, governance, willingness to participate and size of the community are important factors that are discussed through joining, satisfaction and dropping out of the community participants.

\subsection{Interviews}

After the literature review, nine semi-structured interviews were conducted to gain a deeper understanding of TEC initiatives and to narrow down the number of factors that were found in the literature (main focused factors in Table 1) to a limited set of factors. The interviewees were stakeholders involved in the Dutch thermal energy transition, mainly at the local level. They included policymakers (municipalities of the Hague and Amsterdam), representatives of communities (from the cities of The Hague and Rotterdam), researchers and energy companies (one energy company, one network company, one consultancy firm and one energy branch organization). All these stakeholders were actively involved in the development of Dutch local heat transition. Interviewees discussed the factors for the formation and continuation of TEC initiatives (with a focus on the factors which are presented in Section 3.1.). Although interviewees elaborated on some of their ideas on a specific case study, the focus of the interviews was on an overall view related to TECs. The main topics for the interview were:

- Definition of a (thermal) energy community and its main components;

- Differences between thermal energy communities and electrical energy communities; 
- Importance of thermal energy communities in the energy transition at the local level;

- Availability and suitability of renewable thermal energy technologies which can be used at the community level;

- Challenges and factors which influence the formation and continuation of thermal energy communities;

- Main social and governance challenges and factors;

- Main interactions between stakeholders;

- Challenges and factors that could influence the formation and continuation of thermal energy communities;

- Current agenda and planning for deployment of renewable thermal energy systems at the community level.

Three components of energy community definition, technologies (e.g., geothermal and solar) stakeholders (e.g., households and municipality) and institutions (e.g., energy policies and incentives), were discussed in detail in the context of TECs. From this, we extracted the main empirical challenges and factors for the formation and continuation of TECs.

Policymakers at the municipalities and researchers mainly mentioned the financial aspects (e.g., investment and payback time) and size of the neighbourhood (the number of households) as an important factor for the formation and continuation of TEC initiatives. Willingness to participate and the trust among participants, and the influence of these challenges and factors on current and future status of TECs, were also mentioned in these interviews.

Energy companies and representatives of communities also referred to the importance of drop-out processes of unsatisfied households. Although financial aspects were also mentioned, the importance of quitting the energy community when the participants were not satisfied was emphasized. Furthermore, energy companies and also policymakers discussed their ambitions for investments in local energy systems (e.g., district heating) for energy communities. As the Dutch government and municipalities have targets for natural gas free cities, stakeholders, such as municipalities and energy companies, are willing to invest in local energy systems. Energy companies and policymakers extensively elaborated on different renewable thermal energy technologies that are available for this purpose. Geothermal wells, heat pumps, bioenergy and waste-heat, were the main thermal sources in our interviews.

Among the factors which surfaced during the interviews, the size of the neighbourhood, the minimum member requirement and member interactions (such as the satisfaction of members and dropping out) were mentioned most often. Knowledge about these factors was limited, and interviewees raised questions about the influence of these factors on the formation and continuation of TEC initiatives in their current ongoing projects in the Netherlands. There are few studies about these factors, and most of them are empirical studies. The size of the neighbourhood and the minimum member requirement are discussed in empirical studies, such as $[17,20,77]$. Satisfaction and dropping out are discussed mainly in studies related to the characteristics of households and neighbourhoods (e.g., environmental concerns and financial status) [11].

Furthermore, interviewees reflected on the factors which were found in the literature and elaborated on them according to their own ideas. The interviews led to four factors that have an influence on the formation and continuation of TEC initiatives. These will be further explored in our modelling efforts:

- Size of the community;

- Minimum member requirement (formation capability);

- Satisfaction of members;

- Drop-out factor.

Further elaboration about these four factors will be presented in the next section. 


\section{Model Conceptualization}

The purpose of the abstract model is to explore the relation between the four unexplored factors and the formation and continuation of TECs. In this section, first, the main components of the model are presented. Then the structure of the model is introduced. Finally, the experimental setup of our simulations and the model's outputs are discussed.

\subsection{Model Components}

The model consists of agents that represent households. The model also contains various technological options, and various energy plans that households can choose from. The agents join a community initiative based on their personal characteristics (financial benefits, environmental stance, willingness to participate) and their interactions with their peers in the network. Further elaboration on each of these model components, agents, different options (financial options, technological options and energy plans), network and interaction is presented next.

\subsubsection{Agents}

Before joining a TEC initiative, each household evaluates various options and makes a decision based on this evaluation. The options fall into the following categories:

- Financial options;

- Technological options;

- Energy plans.

Financial Options

As mentioned in the literature, financial factors play an important role in the decision making of the agents. For the model, we define a financial package as a combination of three elements:

- Investment: The agent is assigned a random number for how much it is willing to initially invest to join the TEC. Based on existing costs of thermal technologies [78-80], we defined five options for investment: 2500, 5000, 7500, 10,000 and 12,500 euro.

- Monthly payment: Besides the initial investment, the agent also needs to pay a monthly fee. Since the average monthly payment for heating purposes in the Netherlands is 110 euro/month [80,81], there are five options for monthly payments: 50, 75, 100, 125 and 150 euro. The model randomly assigns a value to an agent.

- Payback time: The households also take the payback time of their investment into account. Usually, the expectation for the payback time is between 7 and 20 years $[79,81,82]$. Therefore, the model randomly assigns a value from five options for payback time: 5, 10, 15, 20 and 25 years.

While deciding to join a community, each household calculates a financial package (parameter: idea-about-budget) that is based on the three financial parameters explained above (investment, monthly payment and payback time) (Equation (1)).

$$
\text { Financial package }=\text { investment }+(\text { payback time } \times 12 \times \text { monthly payment })
$$

\section{Technology Options}

The three technological energy generation options that are implemented in the model are:

- Geothermal wells;

- Heat pumps;

- Solar thermal technology.

Solar thermal is the smallest sized technology which is used only for one building (maximum five households). Heat pump technology is the medium-sized technology which is used for up-to five 
buildings (maximum 20 households). Geothermal wells are the biggest sized technologies which are used for more than twenty buildings (maximum 100 households). Although there are other renewable energy technologies (e.g., bioenergy, waste heat), these three are chosen for the following reasons: (1) These three technologies represent different possible sizes for a community. (2) There are existing Dutch thermal energy communities that are working with these three options, which makes them the most viable options in this country. (3) The focus of the model is not on technological feasibility; therefore, a comprehensive set of technologies is not required.

In the model, the assumption is that the initial investment of the households is only spent on thermal energy generation. For the distribution system, the model assumption is that the infrastructure (i.e., district heating) is available for the whole neighbourhood. This assumption is endorsed in the literature $[3,83,84]$ and in interviews with policymakers in the Netherlands. Given that the Dutch government and municipalities, such as Amsterdam and Utrecht, want to meet the targets for natural gas free cities in the coming years, they are willing to provide such infrastructure. In addition, energy companies who are already providing thermal energy for households in the conventional way (e.g., natural gas and electricity), want to be still involved in renewable thermal energy systems and would therefore support the system by providing the distribution infrastructure $[6,21,66,71,73,75,84,85]$. Households' monthly payment is spent on the maintenance of the energy system.

\section{Energy Plans}

The agent follows a certain energy plan. Using the results of our interviews, in a TEC initiative, there could be financial income (when more energy is generated than needed), which would need to be distributed among the members of the community. Three energy plans were implemented in our model, based on the agents' environmental-economic trade-offs $[57,86,87]$. The options were:

- Energy plan for maximizing renewable energy generation: In this plan, agents and the community only focus on maximising the generation of renewable thermal energy and, therefore, contribution to environmental benefit. Therefore, all the available money from the households that join afterwards (investments and monthly payments) will be used to generate as much renewable energy as possible, thus increasing the share of renewable energy in their energy mix consumption

- Energy plan for maximizing the individuals' profit: This plan only focuses on maximizing the economic benefits of the joined households. Therefore, the income is used to give financial benefits to individual households. This plan is the least environmentally friendly.

- Mixed energy plan: This plan is an option between the two other options. In this plan, fifty percent of the available money would be invested in increasing generation of renewable thermal energy, and the rest would be used for economic benefit of the joined households.

\subsubsection{Decision Making}

According to the literature (e.g., [11]), households have incentives, such as environmental concerns, independency, perception of belonging to a community and financial benefits, to make a decision to join energy communities. In this study, the households will make decisions mainly based on financial benefits, environmental concerns and perception of belonging to a community.

At the start of the simulation, all households calculate their own financial package (Equation (1)) and preferences based on the assigned variables. The most popular technology, energy plan and budget/financial package among households would be considered as the final plan for the TEC. After this, households select one of three main choices:

1. Decision to join the community initiative: Each individual household decides whether to join the community based on the comparison of its own idea about the budget with the selected budget of the neighbourhood, and its own energy plan and selected energy plan of the neighbourhood.

2. Decision to join an existing community: There is a possibility for the households to join a community after its formation. In this case, the household would make the decision based on two 
comparisons: first, the comparison of its own idea about the budget with the budget required to join the community project, and second, its own energy plan and current energy plan of the project.

3. Decision to drop out: After the payback time, each individual household inside the community can make a decision to drop out of TEC initiatives. This decision is based on the self-satisfaction of an individual and the satisfaction of its network (Equation (2)). If the individual is unsatisfied and its network is minimally satisfied, after the payback time of a household is passed (otherwise they would make a financial loss), the household will drop out of TEC initiatives.

\subsubsection{Network}

Agents' interaction is determined by a social network model, which in this study is a "small-world" network $[88,89]$. This means households' interactions with their connections (other households in their neighbourhood) depend on the small-world social network structure, which is discussed in [31,90]. In the model, each household has up to 10 other households in its social network [31]. These 10 other households are in the same neighbourhood and are chosen randomly for each agent. According to network's assigned variables and satisfaction, the network of the agent influences its decisions regarding dropping out and joining TEC initiatives after its formation. For instance, if the network of an agent is satisfied, it would have positive influence on the decision of the agent on joining the TEC initiative.

\subsection{Model Structure}

In each round in the simulation, each agent makes a decision to join a TEC initiative or not. In the first step, all households in the neighbourhood are randomly assigned an available investment package and an energy plan. In the next stage, the package and the plan that are most popular among the households will be the selected options for the whole neighbourhood. Then, each individual household will decide about its participation according to the energy plan and the budgets. If the number of households who are participating in the community energy initiative is equal or higher than the required participants for the chosen technology, the community is formed.

The formation of a TEC leads to the start of the generation of thermal energy. After the formation, the important criterion to be calculated is the satisfaction of the households. The satisfaction is based on the comparison between their monthly payments and their previous energy bills and their budget, as shown in Equation (2), which means the satisfaction of a household mainly depends on the financial benefits. In other words, households are satisfied when

$$
\begin{gathered}
(\text { Selected actual budget })<((\text { satisfaction level }) \times \text { idea about budget })) \text { AND } \\
((\text { monthly payment })<((\text { satisfaction level }) \times(\text { previous energy bills })))
\end{gathered}
$$

If they drop out, they return to natural gas consumption. Dropping out is based on the self-satisfaction and the satisfaction of the households' network. As presented in Equation (3), if the individual agent is not satisfied and if unsatisfied households in the agent's network are more than the specific percentage (a parameter that is varied for the experiment), drop out factor * number of join households, after the contract time (payback time) of each household is passed, the household will drop out of the community (Equation (3)).

(satisfaction of an individual household is false) AND (number of satisfied households in the household's network $)<(($ drop out factor $) \times$ (households who participate in the community) $)$

There is always an opportunity to rejoin the community. The households can join an existing TEC throughout the simulation regardless of having joined before or not. Joining an existing TEC initiative is mainly based on two factors: (1) satisfaction of the household's network and (2) comparison of 
the required budget to join the project and the agent's preference about the budget (Equation (4)). Therefore, each individual household will join an existing TEC initiative when:

(number of satisfied households who already joined the community) $>$ ((satisfaction join threshold $) \times($ number of satisfied households in the household's network $))$

$$
\text { AND ((selected actual budget) }>\text { ((afterwards join factor) }
$$

$$
\times \text { (idea about budget)) }
$$

Figure 1 presents the oviewview of model structure.

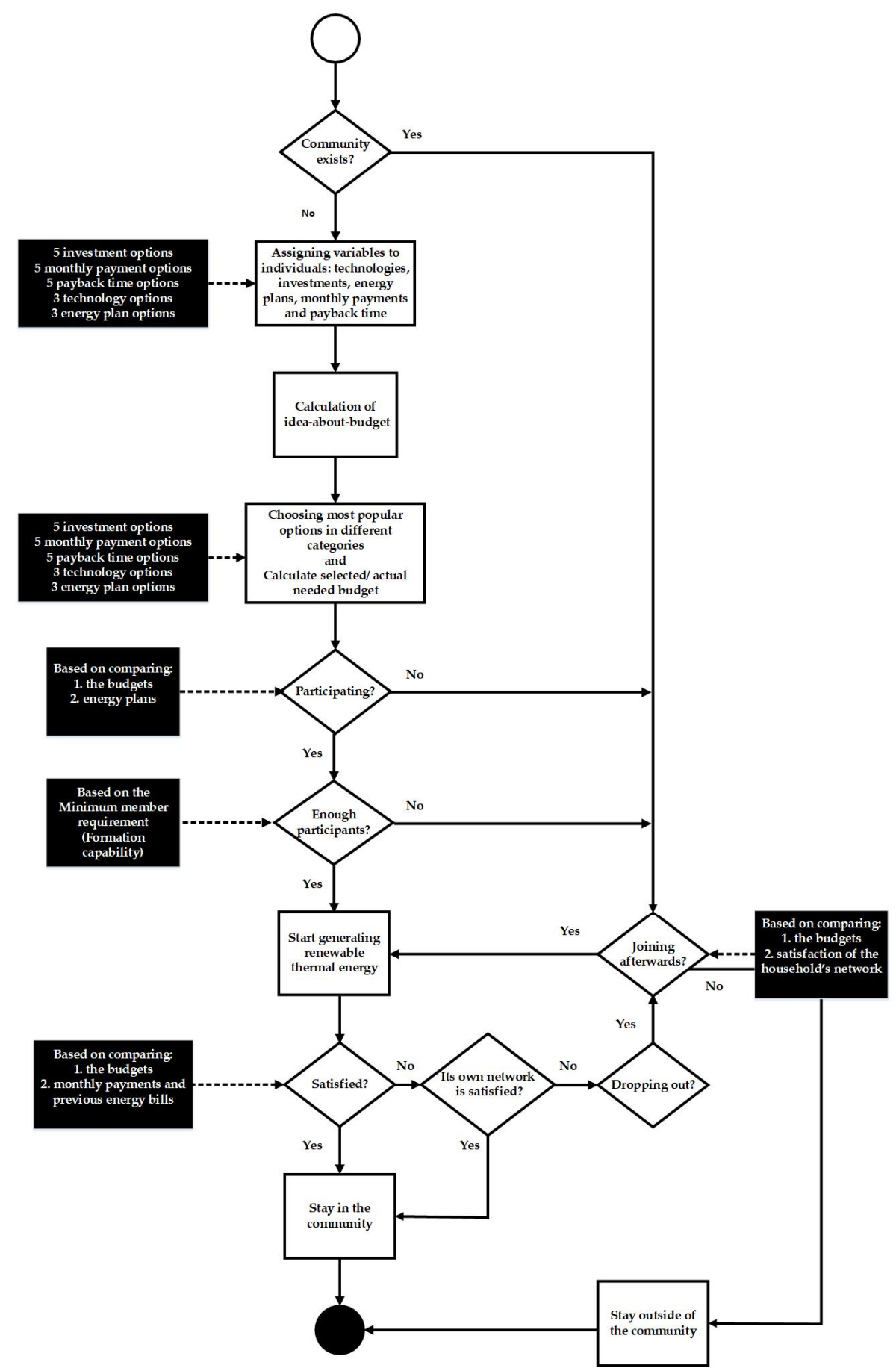

Figure 1. Overview model structure of thermal energy community (TEC) initiatives. 


\subsection{Experimental Setup of Simulation and Factors}

As discussed, the formation and continuation of TEC initiatives can be influenced by four factors which are simulated in the agent-based model as follows:

- Number of households in the neighbourhood:

This input parameter concerns the size of the neighbourhood within which TEC initiatives may be formed. The size of the neighbourhood is equal to the number of households in that neighbourhood. For this model, the number of households has three values: 200, 500 and 700 households, representing three typical sizes of small scale neighbourhoods in the Netherlands.

- Minimum member requirement or formation capability:

This input parameter refers to the minimum percentage of households in the neighbourhood that needs to join TEC initiative at the start, to initiate a community energy system. For this model, minimum member requirement or formation capability has three values: $0.2,0.5$ and 0.8 . These represent the percentage $(20 \%, 50 \%$ and $80 \%)$ of households in the neighbourhood that should join TEC initiatives at the beginning. These values randomly selected to cover the whole range of possible values.

- Satisfaction factor:

This parameter represents the satisfaction of each individual household who has joined a TEC initiative. It is calculated based on the comparison of the initial idea about the budget and the actual invested budget, and the money they earn in terms of energy saving. If the satisfaction factor is set to a smaller number at the beginning, it means the individuals would be satisfied more easily. For this model, the satisfaction factor has three values: $0.5,1.5$ and 2.5 , which will be multiplied to the other aspects of the model, such as the budget. Equation (2) illustrates how this parameter is used in the model.

- Drop-out factor:

This input parameter influences individual households that have joined TEC initiatives but drop out after the contract time. If the drop-out factor is set to a smaller number at the start, it means that the individuals would drop out more easily. For this model, the drop-out factor has three values: 0.2 , 0.5 and 0.8 , representing the percentage of households in agents network compared to all unsatisfied joined households (see Equation (3)).

Since the goal of TECs and also this model is to generate and distribute thermal energy based on renewable energy sources, if the agents do not participate in TECs or drop out from TECs, the conventional form, national natural gas grid, will be the source of thermal energy supply. There are four factors, and each has three options; therefore, we have $3^{4}=81$ scenarios to study. We repeated each run 100 times (to have enough experiments to decrease the influence of the parameters that agents choose randomly (e.g., number of the links with other agents). Therefore, there were 8100 runs in total. The model will run for 50 years, which is the age of an energy infrastructure and technology that is deployed, using time steps of one year.

\subsection{Model Outputs}

To explore the influence of these four factors on the formation and continuation of TEC initiatives, three output variables will be analysed:

- Percentage of joined households:

Percentage of joined households is an indicator of the formation of TEC initiatives. Since the experiments are in different neighbourhood sizes, this output is in percentage (Equation (5)).

Percentage of joined households $=100 \times($ (number of households who joined the community $) /$

(number of households in the neighbourhood)) 
- Percentage of households who joined afterwards:

This variable captures how many of the households in the neighbourhood have joined the TEC initiatives after it has been initiated. This provides information about the process of continuation of thermal energy systems (Equation (6)).

Percentage of households who joined afterwards $=100 \times($ (number of households

who joined the community afterwards)/(number of households in the neighbourhood))

- Satisfaction of the households who joined the community:

This variable reflects the satisfaction and continuation of the TEC initiatives (Equation (7)):

Satisfaction of the households who joined the community $=100 \times($ (number of joined households who are satisfied)/(number of households who joined))

\section{Model Results and Discussion}

In this section, we present the results of our simulation analysis. First, we give an overview of how many TEC initiatives were actually initiated in all 8100 runs. The analysis of four factors (number of households, formation capability, satisfaction factor and drop-out factor) through three outputs (percentage of joined households, percentage of households who joined afterwards and satisfaction of the households who joined the community) are shown in the next Tables. To provide a better understanding and overview, the results are first presented separately for each of the three output variables.

As Table 2 presents, the results show that in $26 \%$ of the model runs, the percentage of joined households was less than $20 \%$ of the whole neighbourhood. According to the interviews, less than $20 \%$ of joined households means the TEC is not initiated. In fact, of this $26 \%$, in $7.5 \%$ of model runs, no household joined a TEC initiative, which shows that there was no community formation at all. In the other $18.5 \%$ of the model runs, the number of the joined households was less than $20 \%$ of the whole neighbourhood. According to the interviews, around $80 \%$ of the neighbourhood need to join to consider the TEC as established, which only happened in $5.7 \%$ of all model runs.

Table 2. Percentage of joined households in each run in 8100 runs.

\begin{tabular}{cccc}
\hline $\begin{array}{c}\text { Percentage of Joined } \\
\text { Households } \\
\text { in Each Run }\end{array}$ & What Does It Mean? & $\begin{array}{c}\text { Number of Runs } \\
\text { with This Output } \\
\text { Out of 8100 Runs }\end{array}$ & $\begin{array}{c}\text { Percentage of Runs } \\
\text { with This Output }\end{array}$ \\
\hline $0-20 \%$ & $\begin{array}{c}\text { No community formed or } \\
\text { survived }\end{array}$ & 2102 & $26 \%$ \\
\hline $20-80 \%$ & $\begin{array}{c}\text { Some communities were formed } \\
\text { and sustained }\end{array}$ & 5530 & $68.3 \%$ \\
\hline $80-100 \%$ & $\begin{array}{c}\text { Most of the neighbourhood } \\
\text { joined a community }\end{array}$ & 468 & $5.7 \%$ \\
\hline
\end{tabular}
Table 3.

The percentage of households who joined after the initial community was formed, is presented in 
Table 3. Percentage of households who joined afterwards in 8100 runs.

\begin{tabular}{cccc}
\hline $\begin{array}{c}\text { Percentage of Joined } \\
\text { Households after Energy } \\
\text { Community Was Formed }\end{array}$ & What Does It Mean? & $\begin{array}{c}\text { Number of Runs } \\
\text { with This Output } \\
\text { Out of 8100 Runs }\end{array}$ & $\begin{array}{c}\text { Percentage of } \\
\text { Runs with } \\
\text { This Output }\end{array}$ \\
\hline $0 \%$ & $\begin{array}{c}\text { No household joined the } \\
\text { community after it was } \\
\text { formed }\end{array}$ & 7083 & $87.4 \%$ \\
$0-20 \%$ & $\begin{array}{c}\text { Less than } 20 \% \text { of the } \\
\text { neighbourhood joined } \\
\text { the community after it } \\
\text { was formed }\end{array}$ & $10.4 \%$ \\
\hline $50 \%$ & $\begin{array}{c}\text { Less than } 50 \% \text { of the } \\
\text { neighbourhood joined } \\
\text { the community after it } \\
\text { was formed }\end{array}$ & $2.2 \%$ \\
\hline
\end{tabular}

Table 3 reveals that in the majority of model runs, households did not join TEC initiatives after their formation. Out of 8100 runs, in 7083 runs, there was no household that joined TEC initiatives after their formation. In $12.6 \%(10.4 \%+2.2 \%)$ of the model runs, fewer than $50 \%$ of households joined TEC initiatives after initiation. There was no run in which more than $50 \%$ of households join the TEC initiatives after initiation.

As presented in Table 4, the satisfaction of households who joined the community was divided mainly between no satisfaction among households or the majority of the joined households were satisfied. In 4958 runs (out of 8100 runs), there was no satisfaction among joined households. In contrast, in 2714 runs, most of the joined households were highly satisfied. These results present a polarized satisfaction, which needs further exploration to find the possible root causes.

Table 4. Percentage of satisfied households in each run in 8100 runs.

\begin{tabular}{cccc}
\hline $\begin{array}{c}\text { Percentage of Satisfied } \\
\text { Households }\end{array}$ & What Does it Mean? & $\begin{array}{c}\text { Number of Runs with } \\
\text { This Output out of } \\
\mathbf{8 1 0 0} \text { Runs }\end{array}$ & $\begin{array}{c}\text { Percentage of } \\
\text { Runs with } \\
\text { This Output }\end{array}$ \\
\hline $0 \%$ & $\begin{array}{c}\text { There is no satisfaction } \\
\text { among households }\end{array}$ & 4958 & $61.2 \%$ \\
\hline $0-80 \%$ & $\begin{array}{c}\text { Some of the households } \\
\text { are satisfied }\end{array}$ & 428 & $5.3 \%$ \\
\hline $80-100 \%$ & Majority of households \\
are satisfied
\end{tabular}

Two of the factors, i.e., the number of households and the formation capability, were analysed further to understand their influence on the model's outputs. This is shown in Figures 2 and 3. 


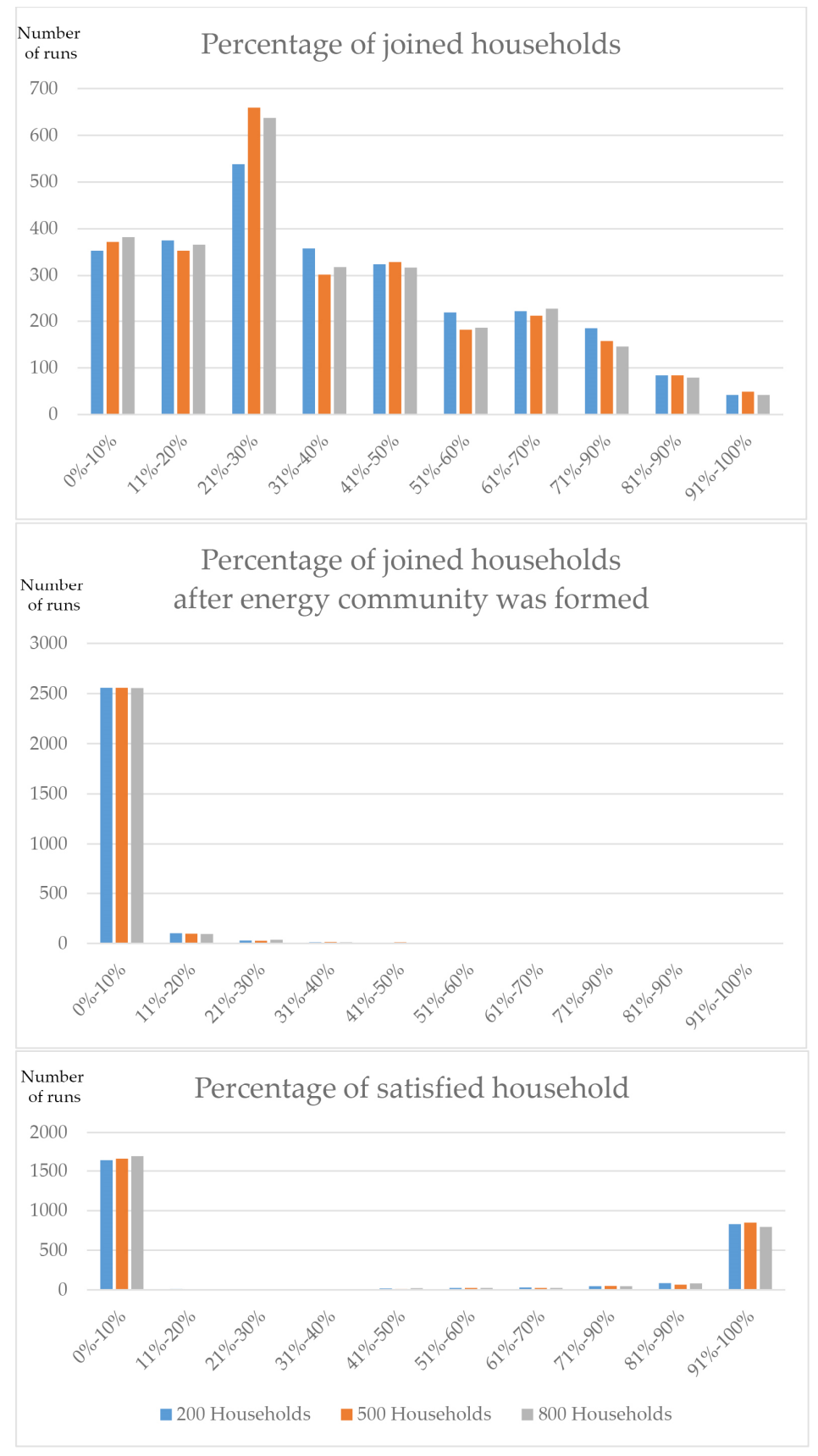

Figure 2. Influence of the number of households on the outputs. 


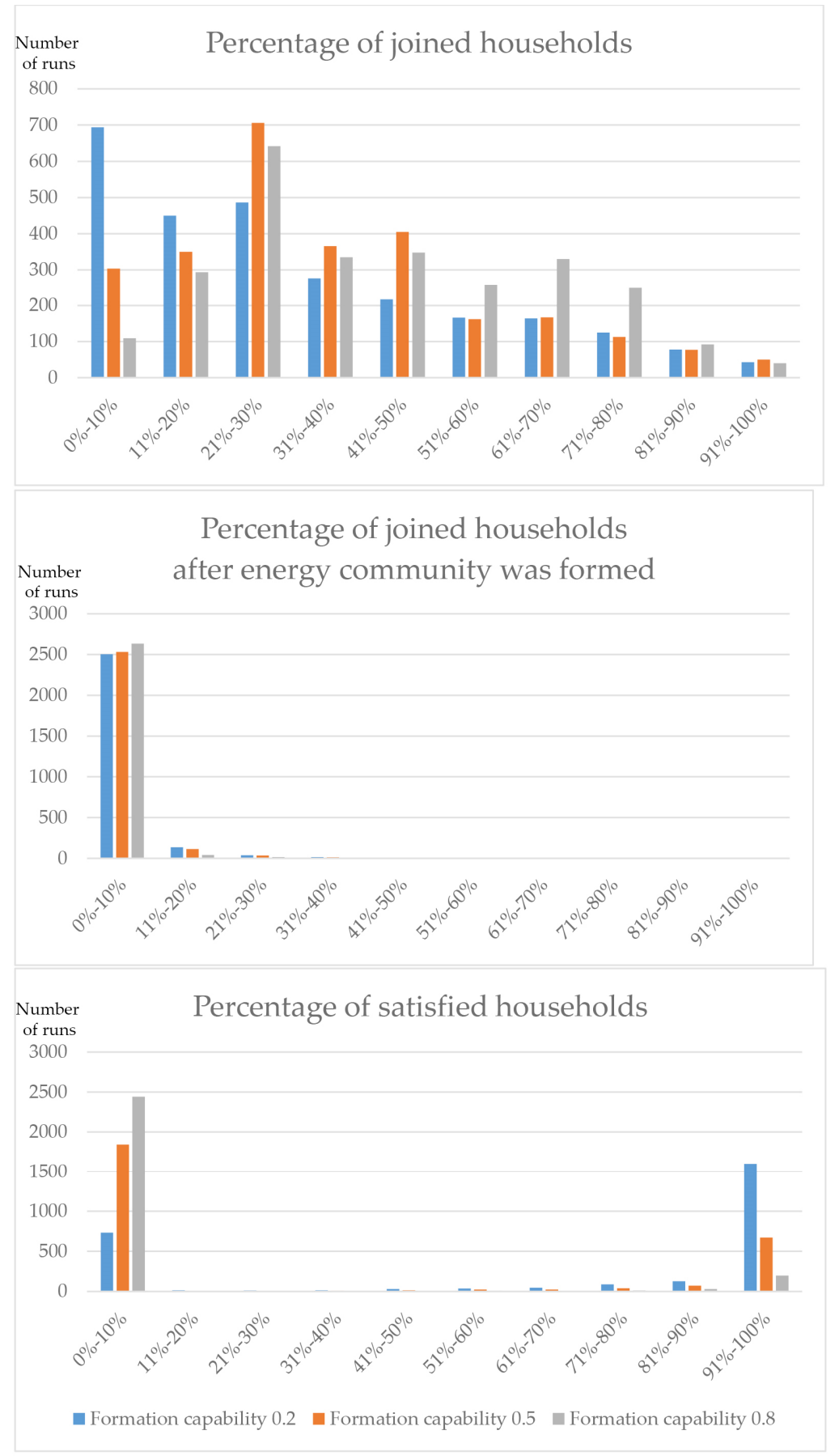

Figure 3. Influence of formation capability on the outputs.

Figure 2 shows that there was no significant impact on the outputs when the number of households was changed. Based on the model's structure and assumptions, the number of households (size of the community) did not have considerable influence on the results.

Figure 3 shows the results for the formation capability (minimum member requirement). As the figure shows, the formation capability had considerable influence on the behaviour of two outputs: the percentage of joined households and the percentage of satisfied households. When the formation capability was changed, the outputs change.

This comparison between the correlation of two factors, number of households and formation capability, on the model's outputs, shows that the influence of factors on the outputs was different. 
To have better insights from the results, the correlation between each factor and each output is presented in Table 5.

Table 5. Correlations between factors and model outputs.

\begin{tabular}{|c|c|c|c|c|}
\hline Factors to & kplore & $\begin{array}{l}\text { Percentage of } \\
\text { Joined } \\
\text { Households }\end{array}$ & $\begin{array}{c}\text { Percentage of } \\
\text { Joined Households } \\
\text { Afterwards }\end{array}$ & $\begin{array}{c}\text { Percentage of } \\
\text { Satisfied Joined } \\
\text { Households }\end{array}$ \\
\hline \multirow{2}{*}{$\begin{array}{l}\text { Number of } \\
\text { households }\end{array}$} & $\begin{array}{c}\text { Pearson } \\
\text { Correlation }\end{array}$ & -0.024 & -0.001 & -0.15 \\
\hline & Sig. (2-tailed) & 0.032 & 0.936 & 0.177 \\
\hline \multirow{2}{*}{$\begin{array}{l}\text { Formation } \\
\text { capability }\end{array}$} & $\begin{array}{l}\text { Pearson } \\
\text { Correlation }\end{array}$ & 0.221 & -0.118 & -0.524 \\
\hline & Sig. (2-tailed) & 0.000 & 0.000 & 0.000 \\
\hline \multirow[t]{2}{*}{ Satisfaction factor } & $\begin{array}{c}\text { Pearson } \\
\text { Correlation }\end{array}$ & 0.388 & 0.49 & 0.218 \\
\hline & Sig. (2-tailed) & 0.000 & 0.000 & 0.000 \\
\hline \multirow[t]{2}{*}{ Drop out factor } & $\begin{array}{c}\text { Pearson } \\
\text { Correlation }\end{array}$ & -0.002 & -0.005 & 0.001 \\
\hline & Sig. (2-tailed) & 0.840 & 0.647 & 0.918 \\
\hline
\end{tabular}

The correlation of formation capability and the satisfaction factor with the model outputs was strong, highlighting the role of satisfaction in the formation of TEC. The satisfaction factor had a positive correlation with all of the model outputs, which means that the satisfaction of households would boost the formation and continuation of TEC initiatives. While the correlation between formation capability and percentage of joined households was positive, the Pearson Correlation was negative between formation capability and the other two model outputs (percentage of joined households afterwards and percentage of satisfied joined households). This means that it is important to incentivise households to join the community at the beginning of its formation because making people join later and increasing satisfaction are hard to achieve.

In contrast, the number of households and the drop-out factor did not show a strong correlation with the model outputs, especially the drop out factor. However, due to the model limitations, this needs further studies.

\section{Model Limitations}

Although this study brought interesting and important insights into light about the formation and continuation of TEC initiatives, it can be developed further to have more in-depth results. All four factors can be structured in the model with more details and complexity, especially the satisfaction factor and drop-out factor. Other related factors, such as available technology and economies of scale, were not captured in this version of the model. Although, size of the neighbourhood and the percentage of participants have an influence on the initial investment of the whole neighbourhood, the assumption in the abstract model is that the chosen technology would not face financial problems in the model (households will successfully provide the needed finances). To provide more insights about technical options, the techno-economic feasibility study of different heating technologies is necessary.

Factors which were already implemented in the abstract model, but are not the focus of the study, such as social aspects (e.g., trust) and financial aspects (e.g., payback time and investment), can be made data-driven to gain more insights about their impact. The technical aspects can be modelled in more detail to understand their role on the formation and continuation of TECs. This would help to have a more comprehensive overview of TECs and the related decision-making processes.

The model is abstract in the sense that the data used to build it were either qualitative (based on interviews) or general statistics (from National websites). This limits the model in exploring the 
influence of actual demographics and characteristics of a given neighbourhood on the formation and continuation of TEC initiatives. Furthermore, since the model did not include detailed financial specifications, the relation between financial packages and the model's results were not explored. This implies that the financing options, such as bank loans, energy company lease, governmental subsidies, and their influence were not studied

In the current version of the model, each neighbourhood had only one energy community. Theoretically, each neighbourhood can have several energy communities. Apart from the values of the household, other aspects, such as technical feasibility, play a role in choosing one of the communities in the neighbourhood for joining. Providing the opportunity for households to choose between different TECs in a neighbourhood, would provide more insights into the households' decision-making process.

To address these limitations, using other qualitative and quantitative approaches would be beneficial. Some examples are:

- Detailed interviews with the main stakeholders: This approach would help to have a better understanding of the responsibilities and strategies of different TEC's stakeholders and the dynamics between them.

- Conducting surveys: This approach would increase the awareness about the social perception and understanding about TECs. Surveys could focus on different topics, such as social acceptance and willingness to participate. Models drawn from such surveys would have a case-specific nature rather than the generalized version we presented in this paper.

- Optimization of the thermal energy system design: This approach would help to have a better technological design for TECs. Different technological designs have differences in their social and governance aspects.

\section{Conclusions and Further Study}

Our research aimed to increase our understanding of the formation and continuation of TEC initiatives. In this paper, we presented the basis of an agent-based model that allowed us to explore four main factors: number of households, formation capability (minimum member requirement), satisfaction factor and the drop-out factor. Their correlation with our model outputs (percentage of joined households, percentage of joined households afterwards and percentage of satisfied households) was investigated, as they are prime indicators for TEC initiative formation and continuation. This model can be deployed for studying certain factors that affect the formation and continuation of TECs. The model provides a simplified version of the real world to provide insights into the potential importance of the factors.

Our preliminary results show that while the formation capability and the satisfaction factor have a strong positive correlation with the percentage of joined households, the number of households and the drop-out factor have relatively weak correlations. Furthermore, both formation capability and the satisfaction factor show a stronger correlation with the percentage of households who joined afterwards and the satisfaction of joined households.

The satisfaction factor has a considerable positive correlation with the percentage of households who joined afterwards. Hence, the model showed that the satisfied households would influence their network to make them join the community or not to drop out of the community. Furthermore, the satisfaction factor has a positive correlation with the percentage of satisfied joined households. In contrast, the number of households and the drop-out factor have weaker correlations with the model's outputs. The negative correlation of the number of households with all the model's output needs further study. Although this model did not investigate the causality between the factors, one of the possibilities for this might be the negative impact of the size of the neighbourhood on the formation and continuation of the thermal energy communities.

Based on preliminary results, the following suggestions to policymakers and households can be made: 
- The size of the neighbourhood (Number of the households) may not be the most important factor to be considered in policies related to the development of TEC initiatives. In other words, to develop policies and strategies to facilitate deployment and establishment of TEC initiatives, there are more important factors to be considered than the size of the neighbourhood.

- It appears to be important that a large enough fraction of households join a community in the beginning. The percentage of the households who join at the beginning of TEC formation seems influential for the continuation of TEC and the satisfaction of participants. Therefore, the focus may need to be on incentivizing households at the beginning to join and participate in the TEC initiatives.

- It seems relatively more important to focus on the satisfaction of the households who joined the community rather than focusing on dropping out of the households.

- If the households do not join at the beginning, it seems relatively hard to join a TEC afterwards. Therefore, it is important to try to incentivize the households in the neighbourhood as much as possible at the beginning. However, there should still be a possibility for households to join a TEC after its establishment.

The results and recommendations would provide new insights for stakeholders to focus on the important factors to further developments of TECs, which leads to the establishment of thermal energy communities. The model presented in this paper is only the start of the modelling effort required to study thermal community energy systems. We are expanding the model further to include more details that make it more representative of actual communities. For that, a more comprehensive data collection will also be pursued. For example, the literature suggests that institutional configurations of such communities are decisive factors for the success of these communities along with individual characteristics, such as willingness to contribute. These factors, among others, are included in the next version of this model. These will provide more concrete recommendations in our future work.

Author Contributions: J.F. built the agent-based model and took the lead in writing the paper. The rest of the authors (N.M., A.G., P.H.) provided feedback on the conceptualization model, verification and validation. They also provided feedback on the paper. All authors have read and agreed to the published version of the manuscript.

Funding: This research was funded by Netherlands Organization for Scientific Research, for their financial support (NWO Responsible Innovation grant-313-99-324).

Acknowledgments: The authors wish to thank the Netherlands Organization for Scientific Research for their financial support.

Conflicts of Interest: The authors declare no conflict of interest.

\section{References}

1. Păceşilă, M.; Burcea, S.G.; Colesca, S.E. Analysis of renewable energies in European Union. Renew. Sustain. Energy Rev. 2016, 56, 156-170. [CrossRef]

2. Verbong, G. Governing the Energy Transition: Reality, Illusion or Necessity; Routledge; Taylor \& Francis Group: Abingdon, UK, 2012.

3. Kern, F.; Smith, A. Restructuring energy systems for sustainability? Energy transition policy in the Netherlands. Energy Policy 2008, 36, 4093-4103. [CrossRef]

4. Koirala, B.P.; Koliou, E.; Friege, J.; Hakvoort, R.; Herder, P. Energetic communities for community energy: A review of key issues and trends shaping integrated community energy systems. Renew. Sustain. Energy Rev. 2016, 56, 722-744. [CrossRef]

5. Van Der Schoor, T.; Scholtens, B. Power to the people: Local community initiatives and the transition to sustainable energy. Renew. Sustain. Energy Rev. 2015, 43, 666-675. [CrossRef]

6. Oteman, M.; Wiering, M.; Helderman, J.-K. The institutional space of community initiatives for renewable energy: A comparative case study of the Netherlands, Germany and Denmark. Energy Sustain. Soc. 2014, 4, 11. [CrossRef] 
7. Guide to Developing a Community Renewable Energy Project; Commission for Environmental Cooperation: Montreal, QC, Canada, 2010.

8. Bauwens, T. Explaining the diversity of motivations behind community renewable energy. Energy Policy 2016, 93, 278-290. [CrossRef]

9. Bauwens, T.; Gotchev, B.; Holstenkamp, L. What drives the development of community energy in Europe? the case of wind power cooperatives. Energy Res. Soc. Sci. 2016, 13, 136-147. [CrossRef]

10. Walker, G.; Devine-Wright, P. Community renewable energy: What should it mean? Energy Policy 2008, 36, 497-500. [CrossRef]

11. Koirala, B.P.; Araghi, Y.; Kroesen, M.; Ghorbani, A.; Hakvoort, R.A.; Herder, P.M. Trust, awareness, and independence: Insights from a socio-psychological factor analysis of citizen knowledge and participation in community energy systems. Energy Res. Soc. Sci. 2018, 38, 33-40. [CrossRef]

12. Walker, G.P.; Devine-Wright, P.; Hunter, S.; High, H.; Evans, B. Trust and community: Exploring the meanings, contexts and dynamics of community renewable energy. Energy Policy 2010, 38, 2655-2663. [CrossRef]

13. Martiskainen, M. The role of community leadership in the development of grassroots innovations. Environ. Innov. Soc. Transit. 2017, 22, 78-89. [CrossRef]

14. Schram, W.; Louwen, A.; Lampropoulos, I.; Van Sark, W. Comparison of the greenhouse gas emission reduction potential of energy communities. Energies 2019, 12, 4440. [CrossRef]

15. Visa, I.; Duta, A.; Moldovan, M.; Burduhos, B.; Neagoe, M. Sustainable Communities. In Solar Energy Conversion Systems in the Built Environment; Green Energy and Technology; Springer: Cham, Switzerland, 2020.

16. Magnusson, D.; Palm, J. Come together-the development of Swedish energy communities. Sustainability 2019, 11, 1056. [CrossRef]

17. Bauwens, T. Analyzing the determinants of the size of investments by community renewable energy members: Findings and policy implications from Flanders. Energy Policy 2019, 129, 841-852. [CrossRef]

18. Heldeweg, M.; Saintier, S. Renewable energy communities as 'socio-legal institutions': A normative frame for energy decentralization? Renew. Sustain. Energy Rev. 2020, 119, 109518. [CrossRef]

19. Persson, U.; Möller, B.; Werner, S. Heat Roadmap Europe: Identifying strategic heat synergy regions. Energy Policy 2014, 74, 663-681. [CrossRef]

20. St. Denis, G.; Parker, P. Community energy planning in Canada: The role of renewable energy. Renew. Sustain. Energy Rev. 2009, 13, 2088-2095. [CrossRef]

21. van Leeuwen, R.P.; de Wit, J.B.; Smit, G.J.M. Review of urban energy transition in the Netherlands and the role of smart energy management. Energy Convers. Manag. 2017, 150, 941-948. [CrossRef]

22. Finney, K.N.; Zhou, J.; Chen, Q.; Zhang, X.; Chan, C.; Finney, K.N.; Swithenbank, J.; Nolan, A.; White, S.; Ogden, S.; et al. Modelling and mapping sustainable heating for cities. Appl. Therm. Eng. Appl. Therm. Eng. 2013, 53, 246-255. [CrossRef]

23. Werner, S. International review of district heating and cooling. Energy 2017, 137, 617-631. [CrossRef]

24. Moshkin, I.; Sauhats, A. Solving district heating optimization problems in the market conditions. In Proceedings of the 57th International Scientific Conference on Power and Electrical Engineering of Riga Technical University (RTUCON), Riga \& Cesis, Latvia, 13-14 October 2016; pp. 1-6.

25. Perez-Mora, N.; Bava, F.; Andersen, M.; Bales, C.; Lennermo, G.; Nielsen, C.; Furbo, S.; Martínez-Moll, V. Solar district heating and cooling: A review. Int. J. Energy Res. 2018, 42, 1419-1441. [CrossRef]

26. Ghorbani, A.; Bravo, G. Managing the commons: A simple model of the emergence of institutions through collective action. Int. J. Commons 2016, 10, 200-219.

27. Minai, A.A.; Bar-Yam, Y. Unifying Themes in Complex Systems, Vol. IIIB: New Research; Springer Publishing Company: New York City, NY, USA, 2007.

28. Vespignani, A. Modelling dynamical processes in complex socio-technical systems. Nat. Phys. 2012, 8, 32-39. [CrossRef]

29. Righi, A.W.; Saurin, T.A. Complex socio-technical systems: Characterization and management guidelines. Appl. Ergon. 2015, 50, 19-30. [CrossRef]

30. Bonabeau, E. Agent-based modeling: Methods and techniques for simulating human systems. Proc. Natl. Acad. Sci. USA 2002, 99 (Suppl. 3), 7280. [CrossRef] [PubMed]

31. Rai, V.; Robinson, S.A. Agent-based modeling of energy technology adoption: Empirical integration of social, behavioral, economic, and environmental factors. Environ. Model. Softw. 2015, 70, 163-177. [CrossRef] 
32. Holtz, G.; Alkemade, F.; De Haan, F.; Köhler, J.; Trutnevyte, E.; Luthe, T.; Halbe, J.; Papachristos, G.; Chappin, É.; Kwakkel, J.H.; et al. Prospects of modelling societal transitions: Position paper of an emerging community. Environ. Innov. Soc. Transit. 2015, 17, 41-58. [CrossRef]

33. Holm, S.; Hilty, L.; Lemm, R.; Thees, O. Empirical validation of an agent-based model of wood markets in Switzerland. PLoS ONE 2018, 13, e0190605. [CrossRef]

34. Moglia, M.; Cook, S.; McGregor, J. A review of Agent-Based Modelling of technology diffusion with special reference to residential energy efficiency. Sustain. Cities Soc. 2017, 31, 173-182. [CrossRef]

35. Couclelis, H. The Certainty of Uncertainty: GIS and the Limits of Geographic Knowledge. Trans. GIS 2003, 7, 165-175. [CrossRef]

36. Macal, C.M.; North, M.J.; Macal, C.M.; North, M.J. Tutorial on Agent-based Modeling and Simulation Agent-based Modeling and Simulation Initiative at Argonne National Laboratory View project AGENT-BASED MODELING AND SIMULATION. In Proceedings of the Winter Simulation Conference, Orlando, FL, USA, 4 December 2005; p. 14.

37. Thiele, J.C.; Kurth, W.; Grimm, V. Facilitating Parameter Estimation and Sensitivity Analysis of Agent-Based Models: A Cookbook Using NetLogo and R. J. Artif. Soc. Soc. Simul. 2015, 17, 11. [CrossRef]

38. Jaccard, M.; Failing, L.; Berry, T. From equipment to infrastructure: Community energy management and greenhouse gas emission reduction. Energy Policy 1997, 25, 1065-1074. [CrossRef]

39. Mavromatidis, G.; Orehounig, K.; Carmeliet, J. A review of uncertainty characterisation approaches for the optimal design of distributed energy systems. Renew. Sustain. Energy Rev. 2018, 88, 258-277. [CrossRef]

40. Lapniewska, Z. Cooperatives governing energy infrastructure: A case study of Berlin's grid. J. Co-op. Organ. Manag. 2019, 7, 100094. [CrossRef]

41. Mahzouni, A. The role of institutional entrepreneurship in emerging energy communities: The town of St. Peter in Germany. Renew. Sustain. Energy Rev. 2019, 107, 297-308. [CrossRef]

42. Huang, Z.; Yu, H. Approach for integrated optimization of community heating system at urban detailed planning stage. Energy Build. 2014, 77, 103-111. [CrossRef]

43. De Boeck, L.; Verbeke, S.; Audenaert, A.; De Mesmaeker, L. Improving the energy performance of residential buildings: A literature review. Renew. Sustain. Energy Rev. 2015, 52, 960-975. [CrossRef]

44. Murphy, R.; Jaccard, M. Energy efficiency and the cost of GHG abatement: A comparison of bottom-up and hybrid models for the US. Energy Policy 2011, 39, 7146-7155. [CrossRef]

45. Brower, M.; Sawin, J.L.; Sverrisson, F.; Chawla, K.; Lins, C.; McMrone, A.; Musolino, A.; Riahi, L.; Sims, R.; Skeen, J.; et al. Renewable 2014 Global Status Report REN21; Reneable Energy Policy Network for the 21st Centry: Paris, France, 2014.

46. Lyden, A.; Pepper, R.; Tuohy, P.G. A modelling tool selection process for planning of community scale energy systems including storage and demand side management. Sustain. Cities Soc. 2018, 39, 674-688. [CrossRef]

47. Rees, M.T.; Wu, J.; Awad, B.; Ekanayake, J.; Jenkins, N. A total energy approach to integrated community infrastructure design. In Proceedings of the 2011 IEEE Power and Energy Society General Meeting, Detroit, MI, USA, 24-28 July 2011; pp. 1-8.

48. Arteconi, A.; Hewitt, N.; Polonara, F. Domestic demand-side management (DSM): Role of heat pumps and thermal energy storage (TES) systems. Appl. Therm. Eng. 2013, 51, 155-165. [CrossRef]

49. Wolisz, H.; Punkenburg, C.; Streblow, R.; Müller, D. Feasibility and potential of thermal demand side management in residential buildings considering different developments in the German energy market. Energy Convers. Manag. 2016, 107, 86-95. [CrossRef]

50. Tronchin, L.; Manfren, M.; Nastasi, B. Energy efficiency, demand side management and energy storage technologies-A critical analysis of possible paths of integration in the built environment. Renew. Sustain. Energy Rev. 2018, 95, 341-353. [CrossRef]

51. Arteconi, A.; Hewitt, N.; Polonara, F. State of the art of thermal storage for demand-side management. Appl. Energy 2012, 93, 371-389. [CrossRef]

52. Negro, S.O.; Alkemade, F.; Hekkert, M.P. Why does renewable energy diffuse so slowly? A review of innovation system problems. Renew. Sustain. Energy Rev. 2012, 16, 3836-3846. [CrossRef]

53. Li, Y.; Jin, M.; Li, Y. Community energy system planning: A case study on technology selection and operation optimization. Procedia Eng. 2017, 205, 2076-2083. [CrossRef] 
54. Boon, F.P.; Dieperink, C. Local civil society based renewable energy organisations in the Netherlands: Exploring the factors that stimulate their emergence and development. Energy Policy 2014, 69, $297-307$. [CrossRef]

55. Energy Policies of IEA Countries-The European Union 2014 Review; European Union: Brussels, Belgium, 2014.

56. Kumar, A.; Sah, B.; Singh, A.R.; Deng, Y.; He, X.; Kumar, P.; Bansal, R. A review of multi criteria decision making (MCDM) towards sustainable renewable energy development. Renew. Sustain. Energy Rev. 2017, 69, 596-609. [CrossRef]

57. McKim, A.E.; Randall, W.L. From Psychology to Poetics: Aging as a Literary Process. J. Aging Humanit. Arts 2007, 1, 147-158. [CrossRef]

58. Von Wirth, T.; Gislason, L.; Seidl, R. Distributed energy systems on a neighborhood scale: Reviewing drivers of and barriers to social acceptance. Renew. Sustain. Energy Rev. 2017, 82, 2618-2628. [CrossRef]

59. Schmidt, D. Low Temperature District Heating for Future Energy Systems. Energy Procedia 2018, 149, 595-604. [CrossRef]

60. Dvarionienè, J.; Gurauskiene, I.; Gecevicius, G.; Trummer, D.R.; Selada, C.; Marques, I.; Cosmi, C. Stakeholders involvement for energy conscious communities: The Energy Labs experience in 10 European communities. Renew. Energy 2015, 75, 512-518. [CrossRef]

61. Brandoni, C.; Polonara, F. The role of municipal energy planning in the regional energy-planning process. Energy 2012, 48, 323-338. [CrossRef]

62. Goedkoop, F.; Devine-Wright, P. Partnership or placation? The role of trust and justice in the shared ownership of renewable energy projects. Energy Res. Soc. Sci. 2016, 17, 135-146. [CrossRef]

63. Woo, J.; Chung, S.; Lee, C.-Y.; Huh, S.-Y. Willingness to participate in community-based renewable energy projects: A contingent valuation study in South Korea. Renew. Sustain. Energy Rev. 2019, 112, 643-652. [CrossRef]

64. Schweizer-Ries, P. Energy sustainable communities: Environmental psychological investigations. Energy Policy 2008, 36, 4126-4135. [CrossRef]

65. Perlaviciute, G.; Steg, L. The influence of values on evaluations of energy alternatives. Renew. Energy 2015, 77, 259-267. [CrossRef]

66. Kalkbrenner, B.J.; Roosen, J. Citizens' willingness to participate in local renewable energy projects: The role of community and trust in Germany. Energy Res. Soc. Sci. 2016, 13, 60-70. [CrossRef]

67. Parag, Y.; Hamilton, J.; White, V.; Hogan, B. Network approach for local and community governance of energy: The case of Oxfordshire. Energy Policy 2013, 62, 1064-1077. [CrossRef]

68. Armstrong, A.; Bulkeley, H. Micro-hydro politics: Producing and contesting community energy in the North of England. Geoforum 2014, 56, 66-76. [CrossRef]

69. Nair, G.; Gustavsson, L.; Mahapatra, K. Factors influencing energy efficiency investments in existing Swedish residential buildings. Energy Policy 2010, 38, 2956-2963. [CrossRef]

70. Vuichard, P.; Stauch, A.; Dällenbach, N. Individual or collective? Community investment, local taxes, and the social acceptance of wind energy in Switzerland. Energy Res. Soc. Sci. 2019, 58, 101275. [CrossRef]

71. Mittal, A.; Krejci, C.; Dorneich, M.C.; Fickes, D. An agent-based approach to modeling zero energy communities. Sol. Energy 2019, 191, 193-204. [CrossRef]

72. Walker, G.P. What are the barriers and incentives for community-owned means of energy production and use? Energy Policy 2008, 36, 4401-4405. [CrossRef]

73. Cipriano, X.; Vellido, A.; Cipriano, J.; Martí-Herrero, J.; Danov, S. Influencing factors in energy use of housing blocks: A new methodology, based on clustering and energy simulations, for decision making in energy refurbishment projects. Energy Effic. 2017, 10, 359-382. [CrossRef]

74. Fay, G.; Udovyk, N. Factors influencing success of wind-diesel hybrid systems in remote Alaska communities: Results of an informal survey. Renew. Energy 2013, 57, 554-557. [CrossRef]

75. Walker, C.; Baxter, J. Procedural justice in Canadian wind energy development: A comparison of community-based and technocratic siting processes. Energy Res. Soc. Sci. 2017, 29, 160-169. [CrossRef]

76. Young, J.; Brans, M. Analysis of factors affecting a shift in a local energy system towards $100 \%$ renewable energy community. J. Clean. Prod. 2017, 169, 117-124. [CrossRef]

77. Franceschinis, C.; Thiene, M.; Scarpa, R.; Rose, J.; Moretto, M.; Cavalli, R. Adoption of renewable heating systems: An empirical test of the diffusion of innovation theory. Energy 2017, 125, 313-326. [CrossRef] 
78. Van Heekeren, V.; Bakema, G. The Netherlands Country Update on Geothermal Energy. In Proceedings of the World Geothermal Congress 2015, Melbourne, Austrilia, 19-25 April 2015; Volume 2013, pp. 2-7.

79. Gudmundsson, O.; Thorsen, J.E.; Zhang, L. Cost analysis of district heating compared to its competing technologies. WIT Trans. Ecol. Environ. 2013, 176, 107-118.

80. Sandvall, A.F.; Ahlgren, E.O.; Ekvall, T. Cost-efficiency of urban heating strategies-Modelling scale effects of low-energy building heat supply. Energy Strateg. Rev. 2017, 18, 212-223. [CrossRef]

81. Studies, I.C. Prices and Costs of Annex 3 Household Case Studies. Available online: https://gaap.ifpri.info/ files/2012/02/Complete_Case_Studies.pdf (accessed on 1 June 2020).

82. Doelgroep, A. Investeringsreglement VvE Energiebespaarlening Nationaal Energiebespaarfonds B. Procedure. Available online: https://www.energiebespaarlening.nl/wp-content/uploads/2019/03/InvesteringsreglementVvE-Nationaal-Energiebespaarfonds.pdf (accessed on 1 June 2020).

83. Tambach, M.; Hasselaar, E.; Itard, L. Assessment of current Dutch energy transition policy instruments for the existing housing stock. Energy Policy 2010, 38, 981-996. [CrossRef]

84. Treffers, D.J.; Faaij, A.P.C.; Spakman, J.; Seebregts, A. Exploring the possibilities for setting up sustainable energy systems for the long term: Two visions for the Dutch energy system in 2050. Energy Policy 2005, 33, 1723-1743. [CrossRef]

85. Singh, H.; Muetze, A.; Eames, P. Factors influencing the uptake of heat pump technology by the UK domestic sector. Renew. Energy 2010, 35, 873-878. [CrossRef]

86. Kurahashi, S.; Jager, W. An Electricity Market Game using Agent-based Gaming Technique for Understanding Energy Transition. In Proceedings of the 9th International Conference on Agents and Artificial Intelligence; SciTePress: Setubal, Portugal, 2017; Volume 1, pp. 314-321.

87. Sousa, T.; Soares, T.; Pinson, P.; Moret, F.; Baroche, T.; Sorin, E. Peer-to-peer and community-based markets: A comprehensive review. Renew. Sustain. Energy Rev. 2019, 104, 367-378. [CrossRef]

88. Watts, D.J.; Strogatz, S.H. Collective dynamics of 'small-world' networks. Nature 1998, 393, 440-442. [CrossRef]

89. Amaral, L.; Scala, A.; Barthélémy, M.; Stanley, H.E. Classes of small-world networks. Proc. Natl. Acad. Sci. USA 2000, 97, 11149-11152. [CrossRef]

90. Latora, V.; Marchiori, M. Efficient behavior of small-world networks. Phys. Rev. Lett. 2001, 87, 198701-1-198701-4. [CrossRef] 